\title{
DePaulUniversity
}

Volume 58

Issue 4 Summer 2009: In Memoriam Professor

James W. Colliton

\section{Trafficking in Trademarks: Setting Boundaries for the Uneasy Relationship between "Property Rights" and Trademark and Publicity Rights}

Sheldon W. Halpern

Follow this and additional works at: https://via.library.depaul.edu/law-review

\section{Recommended Citation}

Sheldon W. Halpern, Trafficking in Trademarks: Setting Boundaries for the Uneasy Relationship between "Property Rights" and Trademark and Publicity Rights , 58 DePaul L. Rev. 1013 (2009)

Available at: https://via.library.depaul.edu/law-review/vol58/iss4/7

This Article is brought to you for free and open access by the College of Law at Digital Commons@DePaul. It has been accepted for inclusion in DePaul Law Review by an authorized editor of Digital Commons@DePaul. For more information, please contact digitalservices@depaul.edu. 


\title{
TRAFFICKING IN TRADEMARKS: SETTING BOUNDARIES FOR THE UNEASY RELATIONSHIP BETWEEN "PROPERTY RIGHTS" AND TRADEMARK AND PUBLICITY RIGHTS
}

\author{
Sheldon W. Halpern*
}

\section{Introduction: Trademarks and Intellectual Property}

Trademark law isn't fun anymore. Until quite recently, trademark law was something of a refreshing outlier in the overheated world of intellectual property theory. Most observers ${ }^{1}$ did not become exercised over the social implications or cultural consequences of trademark law; after all, it was just about money and who was in the best position to profit from the exploitation of certain words, phrases, and pictures in connection with the sale of goods or services. Unlike copyright, which is predicated on at least a modicum of creativity, and unlike the novelty-centered field of patent law, trademark, a kind of hybrid afterthought, is a marketing construct whose justification cannot be found in the improvement of culture or society. As I have suggested elsewhere, "[w]hile affecting the pocket, trademark problems generally do not touch the soul of society."2 The result was that one could simply enjoy the sometimes interesting, sometimes foolish, sometimes creative, and sometimes just plain silly problems presented in trademark litigation. For the teacher and for the student, if not for the practitioner, it was really just fun. The continuing efforts of the Mattel corporation to protect the virtue and reputation of Barbie, ${ }^{3}$ for example, while producing interesting legal analysis, also produces chuckles.

(C) 2009 Sheldon W. Halpern.

* Harold R. Tyler, Jr. Chair in Law and Technology, Albany Law School; C. William O'Neill Professor of Law and Judicial Administration, Emeritus, Moritz College of Law at The Ohio State University.

1. "Except at the margins, among those few who look for assaults on the 'public domain' in hidden places, discussions of trademark matters usually engender little excitement." Sheldon $W$. Halpern, A High Likelihood of Confusion: Wal-Mart, TrafFix, Moseley, and Dastar-The Supreme Court's New Trademark Jurisprudence, 61 N.Y.U. ANN. SuRv. AM. L. 237, 237 (2005).

2. Id.

3. See, e.g., Mattel, Inc. v. MCA Records, Inc., 296 F.3d 894, 898 (9th Cir. 2002) ("SpeechZilla meets Trademark Kong."). 
For good or ill, these carefree days are fast fading into the past. Commentators (including me) point to the explosive growth of trademark law. ${ }^{4}$ Modern trademark law, born in the $1946{\text { Lanham } \text { Act }^{5} \text { as }}^{\text {La }}$ a federal remedial device for enforcing common law "unfair competition" claims, ${ }^{6}$ has, with help from its judicial midwives, ${ }^{7}$ spread and expanded much like kudzu. It has transformed, or morphed, from " a simple subset of the law of unfair competition to a multifaceted remedial scheme,"8 and "trademark theory" has become a popular source of legal scholarship. ${ }^{9}$

As the Supreme Court sees it, the principal function of "classic" trademark law had been to protect the consuming public from being defrauded by one person's use of another's trademark. ${ }^{10}$ Thus the central issue is the likelihood that the consuming public will be "confused" as to the source or origin of the goods or services to which the trademark related. ${ }^{11}$ It has been argued that a more accurate, historical justification for trademark law focuses on the producer rather than the consumer of the goods, and trademark law is directed toward preventing the diversion of trade by means of unauthorized use of one producer's trademark by a competing producer. ${ }^{12}$ Thus, trademark law is a subset of the broader law of unfair competition. In either case, the relationship of trademark law to the fundamental structure of "intellectual property" law is, at best, tenuous and incidental. Neither of these teleological constructs involves matters of originality, creativity, or novelty, the indicia of intellectual activity underlying in-

4. See, e.g., Halpern, supra note 1, at 237-38; Mark A. Lemley, The Modern Lanham Act and the Death of Common Sense, 108 Y ALE L.J. 1687, 1688 (1999) ("Courts protect trademark owners against uses that would not have been infringements even a few years ago and protect as trademarks things that would not have received such protection in the past.").

5. Lanham Act, ch. 540, 60 Stat. 427 (1946) (codified as amended at 15 U.S.C. $\$ \S 1051-1129$ (2006)).

6. Moseley v. V Secret Catalogue, Inc., 537 U.S. 418, 428 (2003) (stating that traditional trademark law "was largely codified in the Trademark Act of 1946 (Lanham Act)").

7. For a review of the early development of trademark law at the federal level, see David S. Welkowitz, The Supreme Court and Trademark Law in the New Millennium, 30 WM. Mitchell L. REv. 1659, 1660-64 (2004).

8. Halpern, supra note 1, at 238; Mark P. McKenna, The Normative Foundations of Trademark Law, 82 Notre DAmE L. Rev. 1839, 1896 (2007) ("Courts, with some help from Congress, significantly broadened trademark law during the twentieth century.").

9. See, e.g., McKenna, supra note 8, at 1903; Graeme B. Dinwoodie \& Mark D. Janis, Confusion Over Use: Contextualism in Trademark Law, 92 IowA L. Rev. 1597 (2007); Stacey L. Dogan \& Mark A. Lemley, Grounding Trademark Law Through Trademark Use, 92 IowA L. REv. 1669 (2007).

10. See Dastar Corp. v. Twentieth Century Fox Film Corp., 539 U.S. 23, 32 (2003).

11. See Robert C. Denicola, Institutional Publicity Rights: An Analysis of the Merchandising of Famous Trade Symbols, 62 N.C. L. REv. 603, 605-06 (1984).

12. McKenna, supra note 8 , at $1840-41$. 
tellectual property. Only at the simplest level of abstraction-the intangible nature of trademark rights-do we find commonality supporting the joinder of copyright, patent, and trademark.

But joined they are, however mismatched, and "trademark" necessarily is part of the triumvirate of basic intellectual property constructs. We therefore must ultimately deal with the "property" aspects of trademark rights, a not unusual situation in the law where application of a label requires us to rationalize that label. Accordingly, we find theoretical discussion of the function of trademark law often framed in Chicago School law and economics terms as an instrument of consumer efficiency. As a means of limiting transaction costs, the trademark serves as a shorthand descriptor of the source and quality of goods and services, eliminating the need for deeper consumer investigation in making purchasing decisions. ${ }^{13}$ As the Supreme Court observed:

[Trademark law,] by preventing competitors from copying "a source-identifying mark," "reduce[s] the customer's costs of shopping and making purchasing decisions," and "helps assure a producer that it (and not an imitating competitor) will reap the financial, reputation-related rewards associated with a desirable product." 14

As long as trademark disputes were limited to those between competing offerors of goods and services, the debate over whether trademark law should be considered consumer-centered or producer-

13. See, e.g., Ty Inc. v. Perryman, 306 F.3d 509, 510 (7th Cir. 2002). According to Judge Posner:

The fundamental purpose of a trademark is to reduce consumer search costs by providing a concise and unequivocal identifier of the particular source of particular goods. The consumer who knows at a glance whose brand he is being asked to buy knows whom to hold responsible if the brand disappoints and whose product to buy in the future if the brand pleases. This in turn gives producers an incentive to maintain high and uniform quality, since otherwise the investment in their trademark may be lost as customers turn away in disappointment from the brand.

Id.; see Lemley, supra note 4, at 1687 ("Most economists today view trademarks as valuable aids to efficient markets.").

14. Dastar, 539 U.S. at 34 (quoting Qualitex Co. v. Jacobson Prods. Co., 514 U.S. 159, 163-64 (1995)). Cf. Smith v. Chanel, Inc., 402 F.2d 562, 566 (9th Cir. 1968). As the Ninth Circuit explained:

Preservation of the trademark as a means of identifying the trademark owner's products ... serves an important public purpose. It makes effective competition possible in a complex, impersonal marketplace by providing a means through which the consumer can identify products which please him and reward the producer with continued patronage. Without some such method of product identification, informed consumer choice, and hence meaningful competition in quality, could not exist.

Id. 
centered, ${ }^{15}$ while interesting, did not carry serious consequences. Similarly, in the context of disputes limited to business competitors, it did not matter much whether one considered "use" or "confusion" the linchpin of trademark law, ${ }^{16}$ as both of those factors were inevitably part of a determination of liability. So, too, within that limited context, it did not matter much how one rationalized the "property" nature of trademark rights. The problem, of course, is that modern trademark disputes, particularly those that have arisen since the advent of the Internet, are not limited to the traditional "unfair competition" context.

Whether the differences are in degree or in kind, the Internet provided a challenge to traditional trademark constructs. At the simplest level, the Internet could be viewed as one of a variety of media, so that the trademark-related questions arising from using another's mark in connection with the offering of goods or services on an Internet website could be dealt with as a "classic" infringement situation, in which the specific medium is irrelevant and the dispute is resolved by application of traditional trademark principles. Thus, a website offering jewelry, while prominently displaying the classic Tiffany color, would be vulnerable to a trademark infringement claim from Tiffany. In considering such a claim, the fact that the use of the mark occurred in the context of a website rather than a print advertisement would be immaterial, and the dispute would be determined by considering the strength and validity of the Tiffany color as a mark and the likelihood of consumer confusion. Similarly, if the Tiffany color were used to draw the websurfer further into the site, where confusion might be dissipated, the "initial interest confusion" problem ${ }^{17}$ could be assessed without significant reference to the Internet as the medium.

But the Internet as a medium has provided the setting for unorthodox, or at least unanticipated, uses of trademarks in ways quite different from those underlying traditional infringement claims. For example, Dogan and Lemley and Dinwoodie and Janis, through conflicting approaches, provide examples of the kinds of issues presented in this nontraditional context (such as the use of meta-tags and embedded matter in search engines and an expansive approach to what is

15. Compare McKenna, supra note 8, at 1896-1915, with Dinwoodie \& Janis, supra note 9, at 1599.

16. Compare Dinwoodie \& Janis, supra note 9, at 1599 , with Dogan \& Lemley, supra note 9 , at 1679.

17. See Brookfield Commc'ns v. W. Coast Entm't, 174 F.3d 1036 (9th Cir. 1999); Gibson Guitar Corp. v. Paul Reed Smith Guitars, 423 F.3d 539 (6th Cir. 2005). 
"initial interest confusion"). ${ }^{18}$ This in turn has given rise to complex questions of the nature of trademark law as a remedial device.

The response to the specifically Internet-based problems created by Internet domain names that are identical with or confusingly similar to trademarks is particularly interesting. The advent of "cybersquatting," the registration as a domain name of another's trademark (e.g., cocacola.com), created a challenge to traditional trademark constructs that, after a period of confusion, was met by sui generis legislation. The paradigmatic case of cybersquatting involved registration of a theretofore unregistered domain name for the express purpose of pressuring the trademark owner to buy the name from the registrant. ${ }^{19}$ In this situation and variants, initially the courts were faced with trying to fit the registrant's use of another's mark into the framework of "use," "use in commerce," and "likelihood of confusion," producing strained and unsatisfying results (legally, if not morally). A brief attempt was made, after enactment of the Federal Trademark Dilution Act, ${ }^{20}$ to fit the cybersquatting scenario into the somewhat more hospitable "dilution" environment. Again, it was clear that the shapes of the pegs and the holes were significantly different and the matter was essentially settled by special purpose legislation ${ }^{21}$ and a more robust Internet practice. ${ }^{22}$ In short, it became apparent that the problems were not, at their root, "trademark" problems, but something qualitatively different, to be dealt with by means of other, albeit special purpose, constructs.

Although the "solution" to these essentially non-trademark Internet-based problems appears to have been found in sui generis legislation, it is instructive that the initial attempt to deal with them was by a protean application of trademark constructs. It was enticing to use these constructs, as the issues arose in the context of continually broadening trademark protection, both with respect to marks registered under the Lanham Act and to unregistered marks for which protection is sought under section 43(a) of the Act. ${ }^{23}$ The response to these developments was a renewed focus on the nature of trademark itself, driven by concern that the law had moved radically from recognition of a simple subset of the law of unfair competition, a limited

18. Dinwoodie \& Janis, supra note 9, at 1632-36; Dogan \& Lemley, supra note 9, at 1691.

19. Panavision Int'l, L.P. v. Toeppen, 141 F.3d 1316 (9th Cir. 1998).

20. Lanham Act $\$ 43$ (c), 15 U.S.C. $\$ 1125$ (c) (2000) (amended 2006).

21. Anti-Cybersquatting Consumer Protection Act, Lanham Act $\S 43(d), 15$ U.S.C. \$1125(d).

22. See ICANN, Uniform Domain Name Dispute Resolution Policy (1999), http://www.icann. org/en/dndr/udrp/policy/htm.

23. Halpern, supra note 1 , at $239-41$. 
"right appurtenant" to the sale of goods or services, ${ }^{24}$ to recognition of some form of stand-alone instrument, embodying a property-like interest akin to copyright or similar interests having an independent value. Whether from a property perspective, a consumer perspective, or a producer perspective, and whether one focuses on "use" or on "confusion," there is consensus that "modern trademark law differs fundamentally from its traditional counterpart in its understanding of what a trademark does and how it adds value."25

What is left unsaid, even with this consensus, is how we are to define, quantify, and to what extent, if at all, protect, that "value." In short, what boundaries are to be set for this redefined concept? Much as with related concerns over the "commodification" of personality that has colored (if not distorted) the debate over the analogous right of publicity, ${ }^{26}$ discussions of whether a trademark is or is not a form of "property" and whether "propertization" 27 of trademarks is a bad thing for the well-being of society ${ }^{28}$ are interesting and important to the formulation of policy. However, they do not move us forward significantly in the necessary search for meaningful boundaries in defining trademark rights. The reality is that the trademark owners-the branding enterprises-will inevitably seek to expand the strength, power, and scope of trademarks. ${ }^{29}$ Such expansion may be harmful to consumers, in possibly limiting choices, or beneficial to consumers in minimizing the possibility of "confusion" and maximizing consumer efficiency. Our concern should not be whether there is some abstract virtue-or some inherent vice-in an expansive approach to trademark. Rather, the issue is keeping trademark law (and its analogues,

24. McKenna, supra note 8, at 1885 (quoting Hanover Star Milling Co. v. Metcalf, 240 U.S. 403, 413-14 (1916)). "Courts traditionally saw a trademark as little more than a vehicle through which consumers could match products with their producers." Id. at 1843.

25. Id. at 1843.

26. See infra notes $93-171$ and accompanying text.

27. "Propertization" is a truly awful word. See, e.g., Lemley, supra note 4, at 1693-94.

28. Id. at 1695-96. According to Lemley:

[P]ropertizing trademarks comes at a rather significant cost to society. Sometimes that cost takes the form of lost opportunities: Important political and social commentary and works of art may be suppressed entirely. It may also take the form of higher prices: When we protect the design of products as trademarks, we prevent competition in the sale of those products, and the price goes up accordingly. Other social costs are more diffuse, but no less real: Our language and our culture are impoverished when we cannot use the most familiar words to discuss-or make fun of, or criticize-the products and companies that are the basis of our economy. ... The more we propertize, the more transaction costs we impose on everyone.

Id. at 1696.

29. See, e.g., Stacey L. Dogan \& Mark A. Lemley, The Merchandising Right: Fragile Theory or Fait Accompli?, 54 EMORY L.J. 461, 462 n.6 (2005). 
such as the right of publicity) consistent with the constitutional and peculiarly American approach to matters affecting this corner of "intellectual property" rights and particularly with the way in which boundaries are set in the context of de facto monopoly power. This brings us to the United States Supreme Court.

\section{Constitutional Boundaries}

Between 2000 and 2004, the Supreme Court decided five trademark and trademark-related cases: Wal-Mart, ${ }^{30}$ TrafFix, ${ }^{31}$ Moseley, ${ }^{32}$ Dastar, ${ }^{33}$ and KP Permanent Makeup. ${ }^{34}$ As I have suggested elsewhere, these cases, while facially quite unrelated and distinct, produced a set of opinions which "sweep majestically (if a bit absentmindedly as to what's left in their wake) into the policy debate over the proper scope of trademark law and its interaction with intellectual property law. Whether one agrees or disagrees with the individual determinations, the ambitious objectives of these cases is impressive." 35

At the core of these opinions--decided not long after the Court signaled an expansive approach to trademark law ${ }^{36}$-is the Court's clear concern with constitutional balance, a determination that trademark law, whatever its underpinnings, should not be used in a manner that can subvert the constitutionally limited monopolies of copyright and patent law and the scope of permissible public use. Thus, the WalMart and TrafFix opinions do not simply place serious limits on the use of trademark law to protect product design. ${ }^{37}$ These opinions

30. Wal-Mart Stores, Inc. v. Samara Bros., 529 U.S. 205, 205 (2000) (discussing "distinctiveness" with respect to trade dress).

31. TrafFix Devices, Inc. v. Mktg. Displays, Inc., 532 U.S. 23, 23 (2001) (discussing trade dress and "functionality").

32. Moseley v. V Secret Catalogue, Inc., 537 U.S. 418, 429-34 (2003) (providing standards for federal dilution claims).

33. Dastar Corp. v. Twentieth Century Fox Film Corp., 539 U.S. 23, 31-38 (2003) (determining "origin" for the purposes of Lanham Act $\S 43(a))$.

34. KP Permanent Make-Up, Inc. v. Lasting Impression I, Inc., 543 U.S. 111, 111 (2004) (interpreting "fair use" as a defense to trademark infringement).

35. Halpern, supra note 1, at 271.

36. See Qualitex Co. v. Jacobson Prods. Co., 514 U.S. 159, 162 (1995) (finding that color can be a registerable trademark while noting that the Lanham Act describes the universe of things that can qualify as a trademark "in the broadest of terms"); Two Pesos, Inc. v. Taco Cabana, Inc., 505 U.S. 763, 763 (1992) (holding that "trade dress" is not to be treated under standards of protection different from those applicable to other kinds of marks and that the law can recognize "inherently distinctive" trade dress).

37. In a brief unanimous opinion, the Court in Wal-Mart adopted a categorical rule to the effect that product design, as a matter of law, cannot be "inherently distinctive," but can be protected only upon a showing that the design has acquired secondary meaning. Wal-Mart Stores, Inc. v. Samara Bros., 529 U.S. 205, 215 (2000). In TrafFix, the Court, while formulating a more stringent test of nonfunctionality for trade dress, held that the existence of an expired 
also, by implication in Wal-Mart, and more directly in TrafFix, attempt to inhibit the prospect of trademark law impinging on the boundaries and limitations of patent law:

[I]n Wal-Mart ... we were careful to caution against misuse or overextension of trade dress. We noted that "product design almost invariably serves purposes other than source identification."

Trade dress protection must subsist with the recognition that in many instances there is no prohibition against copying goods and products. In general, unless an intellectual property right such as a patent or copyright protects an item, it will be subject to copying. As the Court has explained, copying is not always discouraged or disfavored by the laws which preserve our competitive economy. Bonito Boats, Inc. v. Thunder Craft Boats, Inc., 489 U.S. 141, 160 (1989). Allowing competitors to copy will have salutary effects in many instances. ${ }^{38}$

Unstated here, although more explicitly stated in Wal-Mart, is that the "salutary effects" that Justice Kennedy refers to in TrafFix are to be found in consumer benefits. ${ }^{39}$ As Justice Scalia put it in Dastar, ${ }^{40}$ "[t]he words of the Lanham Act should not be stretched to cover matters that are typically of no consequence to purchasers." 41

What makes the Court's discussion of permissible copying of particular interest is Justice Kennedy's reference to the Court's 1989 Bonito Boats opinion, introducing a theme that was more fully developed in the later Dastar opinion. ${ }^{42}$ Bonito Boats was the culmination of a series of Supreme Court opinions, starting in the 1960s, attempting to clarify issues of federal preemption arising from state-based actions predicated on copying of useful articles. Beginning with the companion Sears $^{43}$ and Compco ${ }^{44}$ cases, moving through the divisions in the Court a decade later in Goldstein ${ }^{45}$ and Kewanee, ${ }^{46}$ to an apparent reconciliation yet another decade later with Bonito Boats, the Court grappled with the complex problems of federal/state relationships and the conflicting concerns of federal exclusivity and supremacy with re-

utility patent whose claims include the features for which trademark protection is sought creates a strong presumption of functionality, placing a "heavy burden" on the trademark claimant. TrafFix Devices, Inc. v. Mktg. Displays, Inc., 532 U.S. 23, 29-30 (2001).

38. TrafFix, 532 U.S. at 29 (some internal citations omitted).

39. In Wal-Mart Justice Scalia refers to the "relatively great consumer benefit in requiring a demonstration of secondary meaning." Wal-Mart, 529 U.S. at 215.

40. Dastar Corp. v. Twentieth Century Fox Film Corp., 539 U.S. 23 (2003).

41. Id. at 32-33.

42. Id. at 33-34; see Bonito Boats, Inc. v. Thunder Craft Boats, Inc., 489 U.S. 141 (1989).

43. Sears, Roebuck \& Co. v. Stiffel Co., 376 U.S. 225 (1964).

44. Compco Corp. v. Day-Brite Lighting, Inc., 376 U.S. 234 (1964).

45. Goldstein v. California, 412 U.S. 546 (1973).

46. Kewanee Oil Co. v. Bicron Corp., 416 U.S. 470 (1974). 
spect to the constitutionally recognized federal power over patents. ${ }^{47}$ Notwithstanding the preemption context of these opinions, TrafFix and in more explicit detail, Dastar, used them as a springboard for delineating firmer boundaries, if not higher walls, to contain and inhibit an expansive trademark jurisprudence. Where TrafFix was concerned with preventing trademark constructs from crossing the boundaries of patent law, the Dastar Court acted to ensure that trademark law (in the form of Lanham Act section 43(a)) did not trespass upon the limiting principles of copyright law.

The concern over these boundaries is not predicated on some form of logical purity; rather, it arises from the different constitutional bases for the exercise of congressional power with respect to patents and copyrights, on the one hand, and trademark on the other. While Congress is given explicit power, under Article I, Section 8 of the Constitution, to act with respect to copyright and patent, congressional power with respect to trademarks is not express but rather is inferred from the general power of Congress to act with respect to interstate and foreign commerce. ${ }^{48}$ Both the express grant of power as to copyright and patent and the constitutional temporal limitation on that power ${ }^{49}$ contemplate a vigorous and complementary public domain, a constantly growing area in which the public is free to copy those works which either do not qualify for copyright or patent protection or whose protection has expired. Conversely, trademark rights, which derive from the use "in commerce" of a mark that is distinctive in identifying the source or origin of goods or services, will endure, even perpetually, so long as they remain so distinctive. To the extent that trademark rights might serve to expand or extend copyright or patent rights, the complementary constitutional balance is seriously impaired.

As the Court explained in Dastar:

The right to copy, and to copy without attribution, once a copyright has expired, like "the right to make [an article whose patent has expired]-including the right to make it in precisely the shape it carried when patented-passes to the public." "In general, unless an intellectual property right such as a patent or copyright protects an item, it will be subject to copying." The rights of a patentee or copyright holder are part of a "carefully crafted bargain," under which, once the patent or copyright monopoly has expired, the public may use the invention or work at will and without attribution. Thus, in construing the Lanham Act, we have been "careful to cau-

47. Bonito Boats, 489 U.S. at 157-60. See generally Sheldon W. Halpern, Copyright Law: Protection of Original Expression $\$ 5.3$ (2002).

48. See The Trade-Mark Cases, 100 U.S. 82, 86 (1879).

49. U.S. Const. art. I, $\S 8, \mathrm{cl} .8$ (securing the rights of authors and inventors for "limited times"). 
tion against misuse or over-extension" of trademark and related protections into areas traditionally occupied by patent or copyright. ${ }^{50}$

Consistent with this need to recognize and secure the boundaries among trademark, copyright, and patent, the Dastar court held that "origin," for purposes of the Lanham Act, refers to the source of the physical "goods," and not to the underlying intellectual interests embodied in those goods:

In sum, reading the phrase "origin of goods" in the Lanham Act in accordance with the Act's common-law foundations (which were not designed to protect originality or creativity), and in light of the copyright and patent laws (which were), we conclude that the phrase refers to the producer of the tangible goods that are offered for sale, and not to the author of any idea, concept, or communication embodied in those goods. . . To hold otherwise would be akin to finding that $\S 43(\mathrm{a})$ created a species of perpetual patent and copyright, which Congress may not do. ${ }^{51}$

These opinions, with their strong emphasis on the constitutional and policy distinctions among trademark, copyright, and patent law, and their express desire to honor and recognize these distinctions, provide the basis for balancing and setting boundaries for trademark and related rights. The problem of balance emerges most clearly in considering the trademark implications arising from transactions involving the mark itself: merchandising the trademark. Trafficking in the mark, as the source of value for the consumer, lies at the clearest interface between trademark and "property" rights. The analysis here provides the opportunity more clearly to articulate trademark boundaries, while serving as well to create a principled basis for similarly bounding the analogous right of publicity.

\section{III. "Property" Rights: Traffic in the Thing Itself" 52}

\section{A. Making Law I: "Right You Are If You Think You Are"}

The dress code in law schools being what it is, it is not at all unusual to find students in class wearing baseball caps or sweaters or articles of adornment carrying logos of sports teams or of academic institutions. In my trademark class, I will regularly ask the student wearing a New York Yankees cap (i.e., a cap with the "NY" monogram on it) whether he or she thought that the vendor who sold the cap did so

50. Dastar Corp. v. Twentieth Century Fox Film Corp., 539 U.S. 23, 33-34 (2003) (internal citations omitted).

51. Id. at 37.

52. For a detailed review and critique of the general area of trademark "merchandising," see generally Dogan \& Lemley, supra note 29; Denicola, supra note 11. 
under a license from the New York Yankees or, if not, whether the New York Yankees should be able to assert a trademark infringement claim against that vendor. Almost invariably, the student, and the vast majority of the class, will argue that, of course, the Yankees (or the Red Sox, the University of Notre Dame, or any of the other entities or institutions whose mark is so displayed) should be able to control the use and marketing of their logo.

The students will readily concede that, in buying the hat, the purchaser does not care who made it, nor does the purchaser really believe that the Yankees manufactured it or even were in any way involved in the manufacture. Nevertheless, the students will argue that the unlicensed vendor is wrongfully capitalizing on the purchaser's desire to show affinity with or loyalty to the team and that the law therefore must protect the goodwill embodied in the logo and require a license from the trademark owner. As a general matter, the law is responsive to that kind of concern, as it recognizes, expressly in section 43(a) of the Lanham Act with respect to unregistered marks, and by implication with respect to registered marks under section 32 , that an infringement action generally may be sustained upon a showing of unauthorized use of a trademark in a manner that creates a likelihood of confusion not only as to the source or origin of goods or services but also "as to the affiliation, connection, or association" or "sponsorship[] or approval."s3

Therefore, since it is assumed that the law must protect the trademark owner here (whether because of that owner's efforts or creativity, or otherwise), it is reasonable for consumers to assume that the vendor must have been licensed in order to transact business. ${ }^{54}$ That is, the students suggest that, because the public generally believes that the law requires that one who sells an item embodying another's trademark may do so only with permission, ${ }^{55}$ an unauthorized sale will create a likelihood of confusion in the consuming public, if not as to

53. 15 U.S.C. $\S \S 1114,1125(a)(1)(A)(2000) ; 4$ J. Thomas MCCarthy, MCCarthy on Trademarks and Unfair Competition $\$ 23: 8$ (2008). See, e.g., Pebble Beach Co. v. Tour 18 I Ltd., 155 F.3d 526, 536-37 (5th Cir. 1998). There, the court found:

Once a plaintiff's mark or trade dress is found to be protectible, liability for trademark and trade-dress infringement hinges upon whether a likelihood of confusion exists in the minds of potential consumers as to the source, affiliation, or sponsorship of the defendant's product or service due to the use of the allegedly infringing marks or trade dress.

Id.

54. "Perceptions of business practices, however dim or inaccurate, also may generate assumptions regarding sponsorship." Denicola, supra note 11 , at 612 .

55. See, e.g., Dogan \& Lemley, supra note 29 , at 477 (referring to "the widespread belief that [for example,] team-related jerseys are officially licensed by the NFL"). 
the actual source or origin of the product, then as to sponsorship, permission, approval, or authorization. In short, it is a bizarre syllogism. If enough people believe that the law grants trademark owners rights as to certain uses, then the law grants trademark owners rights as to those uses-a strange revisitation of Pirandello's Right You Are if You Think You Are. ${ }^{56}$ Again, the syllogism is not based on a proposition of law arising out of consumer "confusion" as to sponsorship; there is little independent reason to assume such sponsorship absent some external factor, such as an "official" designation. Rather, the assumption of sponsorship arises out of consumer presumptions as to the state of the law. ${ }^{57}$ As one commentator put it:

In this system, rights are bounded only by consumer understanding: If consumers believe a Yankees logo on a hat suggests the Yankees endorsed the maker of the hat, then the Yankees have the right to control that use.

And the available evidence suggests that consumers believe names and creative content, some of which can be protected as trademarks, are subject to substantial control. Assuming consumer beliefs about the use of marks or logos on merchandise even roughly approximate this evidence, modern law has essentially no choice but to respond. ${ }^{58}$

But is "modern law" really without choice here? Certainly, as a general matter, consumer belief as to what a mark signifies is a central part of trademark law. The ubiquity of consumer survey evidence in trademark litigation demonstrates the importance of determining consumer reaction to a mark, but not consumer understanding of the law. What the "consumers believe" in the context of merchandising of the mark itself is not some consensus as to the reality of commercial behavior; it is not the same kind of "belief" that informs the question of whether a mark has obtained secondary meaning, or whether there may be consumer confusion as to the source of a product. Rather than consumer belief, what we have here is something more elliptical and self-referential, consumer assumption (or misapprehension) as to what the law requires, giving rise to a "belief" as to what must have happened, which in turn gives rise to a legal construct that then conforms to that assumption! The difficulty with the liability scenario outlined above is not that liability is predicated on likelihood of confusion as to sponsorship or endorsement, but rather that the perceived

56. See generally Luigi Pirandello, So It Is (If You Think So), in Six Characters in Search of an Author and Other Plays 137 (trans. Mark Musa, Penguin Books 1995) (using an English translation of the title).

57. "[Liability] rests ... on the often fortuitous circumstance that a particular consumer population is prone to inaccurate assumptions." Denicola, supra note 11, at 613.

58. McKenna, supra note 8, at 1911-12. 
need for authorization, sponsorship, or endorsement arises from the consumers' assumption about the law itself and the perceived unlawful nature of the activity. ${ }^{59}$ In short, if a "merchandising" right is to be recognized under these circumstances, then realistically such recognition cannot be predicated on the "fact" of consumer confusion as to origin or sponsorship of the objects of sale.

To a fair extent, the underlying consumer assumption about the state of the law seems to reflect the coupling of the existence of a lucrative market with an uncritical aversion to "free riding." Certainly, merchandising of the trademark itself is a large, highly profitable business. ${ }^{60}$ Quite apart from the ubiquitous market in professional sports-related materials, licensing. of collegiate trademarks has exploded to the point that these marks have become substantial assets of the educational institutions. ${ }^{61}$ There is no question that, in terms of marketplace reality, there is serious "value" in certain trademarks. That perceived value, in turn, causes the students in my example to characterize the unlicensed vendor of the cap as opportunistically capitalizing on or exploiting someone else's efforts (i.e., the matrix of associations, positive and negative, conjured up by the Yankees logo) and assume that such conduct cannot be lawful. The fact of "value," and the possibility of its opportunistic exploitation, does not, however, automatically translate into creation of an independent right.

"Free riding" is a relativistic concept, without a real moral core. As Justice Kennedy observed in TrafFix, "copying is not always discour-

59. As Dogan \& Lemley suggest, "this confuses a belief about what the law is with a belief as to what the relationship between two parties is." Dogan \& Lemley, supra note 29, at $486 \mathrm{n} .101$. Interestingly, they also suggest that "[t]he issue is certainly not free from doubt, and we can readily imagine a court concluding that even if the merchandising theory is unpersuasive, perhaps the law has gone too far down that road to turn back now." Id. at 489 . Similarly, Lemley suggests that we may have to live with this elliptical silliness. Lemley, supra note 4, at $1708 \mathrm{n} .106$ ("But if we are committed to basing trademark doctrine on consumer reactions, we are probably stuck with those reactions even if the law itself initially helped create them."). But see Pebble Beach Co. v. Tour 18 I Ltd., 155 F.3d 526, 544 n.10 (5th Cir. 1998). There, the court, considering surveys, said it must "caution litigants to consider the language of the survey and questions so that the consumer's belief that permission is required does not skew the results of the survey, thus decreasing its probative value." Id.

60. See Dogan \& Lemley, supra note 29, at 461 (noting that sports and college related trademark marketing generated approximately twenty billion dollars in revenues from 2001-2003).

61. As one commentator noted in 2004:

The prevalence of collegiate licensing has skyrocketed in recent years. Today, approximately three hundred colleges and universities actively license the use of their names and registered trademarks. What began with a primitive licensing arrangement at the University of California at Los Angeles (UCLA) in the 1930s has blossomed into a multi-billion dollar industry.

C. Knox Withers, Sine Qua Non: Trademark Infringement, Likelihood of Confusion, and the Business of Collegiate Licensing, 11 J. INTELl. Prop. L. 421, 434 (2004). 
aged or disfavored."62 While the term is normally used pejoratively in referring to the unauthorized appropriation of someone else's goodwill, the courts have made it clear that the "free rider" is not necessarily an evildoer. Absent special and exceptional circumstances, plagiarism, only in the sense of the taking of another's ideas, generally is not actionable. ${ }^{63}$ Nor, of course, is copying of matter in the public domain. Similarly, one who duplicates precisely the otherwise unprotected scent of, let us say, Chanel No. 5 perfume, and sells the resulting product, correctly labeled and accurately advertised as identical to the scent of Chanel No. 5, is certainly "free riding," but has not violated trademark or any other rights of the competitor, even while "exploiting" the Chanel mark in so doing64:

Disapproval of the copyist's opportunism may be an understandable first reaction, "but this initial response to the problem has been curbed in deference to the greater public good." . . By taking his "free ride," the copyist, albeit unintentionally, serves an important public interest by offering comparable goods at lower prices. On the other hand, the trademark owner, perhaps equally without design, sacrifices public to personal interests by seeking immunity from the rigors of competition. ${ }^{65}$

If one eliminates the opprobrium from "free riding," 66 then the shaky edifice supporting the application of trademark law to merchandising of the mark itself, built on an ephemeral assumption of what the law is, starts to collapse. In short, I suggest that the assumption that the law requires consent of the trademark owner to merchandising of the mark itself flows from "disapproval of the copyist's opportunism" rather than from a factual understanding of the world of merchandise licensing. Perhaps clarity can come from a reframing,

62. TrafFix Devices, Inc. v. Mktg. Displays, Inc., 532 U.S. 23, 29 (2001).

63. See, e.g., Harper \& Row, Publishers, Inc. v. Nation Enters., 471 U.S. 539, 589-90 (1985) (Brennan, J., dissenting). Justice Brennan stated:

A subsequent author's taking of information and ideas is in no sense piratical because copyright law simply does not create any property interest in information and ideas.

The urge to compensate for subsequent use of information and ideas is perhaps understandable. An inequity seems to lurk in the idea that much of the fruit of the historian's labor may be used without compensation. This, however, is not some unforeseen byproduct of a statutory scheme intended primarily to ensure a return for works of the imagination. . . To ensure the progress of arts and sciences and the integrity of First Amendment values, ideas and information must not be freighted with claims of proprietary right.

Id.

64. Smith v. Chanel, Inc., 402 F.2d 562, 569 (9th Cir. 1968).

65. Id. at 568-69 (citing Am. Safety Table Co. v. Schreiber, 269 F.2d 255, 272 (2d Cir. 1959)).

66. "[T]he world is full of free riding." Dogan \& Lemley, supra note 29 , at 480 ; Wendy J. Gordon, On Owning Information: Intellectual Property and the Restitutionary Impulse, 78 VA. L. Rev. 149, 167 (1992) ("A culture could not exist if all free riding were prohibited within it."). 
without the moral opprobrium: one who buys a logo-bearing item (a cap, mug, or T-shirt that is bought in order to show loyalty or affinity to the mark owner) from a vendor displaying an "official" sign, affirmatively stating sponsorship or affiliation between the vendor and the mark owner, may justifiably believe that such affiliation exists. Thus the vendor who falsely makes such a statement would clearly be creating a likelihood of confusion as to "sponsorship." 67 On the other hand, if the consuming public were to believe that the law does not require a vendor selling such items to procure the consent of the trademark owner, then an unlicensed vendor who makes no affirmative statement of "official" sponsorship or affiliation would not be creating a likelihood of confusion as to sponsorship.

Framed in those terms, on what basis, if at all, may liability be imposed? If one accepts both the intrinsic merchandising value of the mark and the tenuous relationship between recognition of an enforceable "merchandising right" and traditional trademark concepts, ${ }^{68}$ then how should the problem be addressed? It is not enough that the mark has "value," as the fact of "value" per se does not generate a right. That is, the fact of "value" (or "interest" or "injury") may support a policy argument that there should be an appropriate right or remedy, but the ultimate policy decision is multi-faceted: the existence of "value" or similar interest is a necessary predicate to a policy determination but is not itself a sufficient basis for it.

\section{B. Making Law II: The Troubles of Job's Daughters}

The case law begins in 1975 with the strained Fifth Circuit analysis in Boston Hockey, where the court held that the unauthorized sale of "patches" containing logos of professional hockey teams infringed the teams' trademarks. ${ }^{69}$ The court conceded that there was no customer confusion as to the source of the patches themselves, but, focusing on the teams as the intellectual "source" of the logos, found the unauthorized sale unlawful. ${ }^{70}$ Here, the court recognized that its decision

67. But see Dogan \& Lemley, supra note 29 , at 478 (suggesting that "the importance of competition counsels in favor of a narrower remedy even in these cases").

68. As Lemley explains:

People buy products like hats and tee-shirts because they have the logo emblazoned on them. This is a rather striking reversal of the normal role of trademark law. Rather than identifying the good with a particular manufacturer, and thereby guaranteeing its quality, the identifier is itself the product. .. . [T]he logo stands alone as a thing that customers value in and of itself.

Lemley, supra note 4, at 1706.

69. Boston Prof'l Hockey Ass'n v. Dallas Cap \& Emblem Mfg., Inc., 510 F.2d 1004, 1011-13

(5th Cir. 1975).

70. Id. at 1012-13. 
would "slightly tilt the trademark laws from the purpose of protecting the public to the protection of the business interests of plaintiffs."71

Not surprisingly, given the shakiness of the rationale, the opinion drew sharp criticism and it was adamantly rejected by the Ninth Circuit in the 1980 Job's Daughters opinion. ${ }^{72}$ Rejecting a trademark infringement claim for the unauthorized sale of rings bearing the logo of the plaintiff sororal organization, the court found Boston Hockey's reasoning not only unpersuasive but misguided in that it "transmogrifies this narrow protection into a broad monopoly."73 Noting that "our reading of the Lanham Act and its legislative history reveals no congressional design to bestow such broad property rights on trademark owners," "74 the court found the Boston Hockey "tilt was not slight but an extraordinary extension of the protection heretofore afforded trademark owners."75

After Job's Daughters, subsequent courts were divided on the issue ${ }^{76}$ even the Fifth Circuit had some reservations. ${ }^{77}$ Perhaps the most interesting of these opinions is the Tenth Circuit's United States v. Giles. ${ }^{78}$ Giles was a criminal prosecution for sale of "counterfeit goods."79 The defendant sold patches consisting of trademarked logos that purchasers could affix to products identified with the trademark owner (e.g., a "Coach" tag to be attached to a handbag). ${ }^{80}$ The court held that the criminal statutory provision relating to "counterfeit" goods "does not forbid the mere act of trafficking in counterfeit labels which are unconnected to any goods." 81 While the criminal provisions and standards for liability are of course different from the ordinary

71. Id. at 1011.

72. Int'l Order of Job's Daughters v. Lindeburg \& Co., 633 F.2d 912, 918-19 (9th Cir. 1980).

73. Id. at 919.

74. Id. at 918 .

75. $I d$. at 919 .

76. See, e.g., Bi-Rite Enters., Inc. v. Button Master, 555 F. Supp. 1188, 1195 (S.D.N.Y. 1983).

There, the court stated:

In this Circuit, marks that are exploited only for their functional value and not to confuse the public receive no protection under unfair competition laws. Functionality in this context means that consumers desire the mark for its intrinsic value and not as a designation of origin. ... When a mark without copyright protection is exploited for its intrinsic functional value, Congress has implicitly determined that society's interest in free competition overrides the owner's interest in reaping monopoly rewards.

Id. (internal citation omitted). See generally Withers, supra note 61 (providing a review of the cases).

77. Kentucky Fried Chicken Corp. v. Diversified Packaging Corp., 549 F.2d 368, 387 (5th Cir. 1977).

78. 213 F.3d 1247 (10th Cir. 2000).

79. Id. at 1251 .

80. See id. at 1251-52.

81. Id. at 1251. 
trademark infringement action, what is of interest here is the court's conclusion that, at least for purposes of the criminal statute, the logo itself (as embodied in the patch) did not constitute "goods." 82 Sharply criticizing Boston Hockey, ${ }^{83}$ the Tenth Circuit, in language to be echoed by the Supreme Court in Dastar, concentrated on the laws' boundaries: since "a trademark is easily conceived of as an abstract symbol or design which is carried by the tangible goods at issue ... $[\mathrm{w}] \mathrm{e}$ will not stretch the trademark statute into an area more appropriate to copyright law." 84

The odd result is the question whether any of this judicial analysis mattered, as the market apparently remained strangely unaffected by the vicissitudes of the courts. While the Boston Hockey-Job's Daughters split exemplifies the state of the law itself, and there appears to be both a vociferous condemnation of the Boston Hockey rationale ${ }^{85}$ and an almost direct rejection of it by the Dastar discussion of "origin," 86 the public perception of a stand-alone merchandising right appears unchanged and the large financial engine for which it serves as the base charges forward. "[T]rademark owners, competitors, and perhaps even consumers act as though the merchandising theory is a fait accompli . ..."87

Such a fait accompli, if it exists, is all the more remarkable in light of the virtual absence of serious congressional or judicial attention to the inherent policy question that Robert Denicola, more than twenty years ago, described as "the persistent failure to address the central question-is it sensible to recognize a monopoly in the merchandising value of famous trade names and symbols?"88 Although the market reality noted above appears firm, as does the public acceptance of the right, the limited judicial approach to this matter, with its almost active avoidance of an attempt to articulate policy, is at best equivocal.

There is certainly a manifest need for dealing with the social policy question of whether there should be express legal recognition of commercial rights in a trademark itself-what we have called a merchan-

82. “Mr. Giles' conduct did not confuse any consumer about the origin of goods because there were no goods involved in the transaction." Id. at 1252-53.

83. Id. at 1250. The Giles court stated that "the [Boston Hockey] court relied upon a novel and overly broad conception of the rights that a trademark entails." Id.

84. Giles, 213 F.3d at $1250,1253$.

85. "The Boston Hockey decision ... effectively precluded the unauthorized merchandising of famous trade symbols without the inconvenience of an explicit analysis." Denicola, supra note 11 , at 607; see also Dogan \& Lemley, supra note 29, at 478 (The authors "conclude that there is no theoretical and little practical justification for such a right.").

86. See supra note 51 and accompanying text.

87. Dogan \& Lemley, supra note 29 , at 506.

88. Denicola, supra note 11 , at 605 . 
dising right. So too, there are strong arguments to be made on that policy level. Thus, while Denicola proposes a form of recognition, ${ }^{89}$ Dogan and Lemley argue strongly against recognition of a merchandising right (an argument epitomized by their related argument against recognition of the trademark owner's claims where the mark is not being used on unrelated goods but is used on "knock-offs" of the trademark owner's products under circumstances in which the consumer is quite aware of the counterfeit nature of the seller's activities). ${ }^{90}$ Nevertheless, this policy debate, although interesting, has limited utility in the context of trademark law. That is, while the merchandising question usually involves use of a trademark in the form of direct trafficking, if there is to be recognition of this kind of right, however limited or circumscribed, that recognition needs to have a more substantial basis than interpretation of trademark principles. In short, much as with the problem of attempting to fit the cybersquatting and related problems into a "trademark" framework, we must ultimately recognize that, however we collectively may resolve the policy question, such resolution must be done outside the parameters of trademark law. Once the circular nature of the "sponsorship confusion" is understood, the trademark underpinnings for recognition of a merchandising right disappears. ${ }^{91}$ That is, the "merchandising" issue is outside the necessary boundaries of trademark law and if any standalone rights are to be recognized, that recognition must be sui generis; outside of the "trademark" monopoly, some tertium quid. ${ }^{92}$

\section{Making Law III: The Analogous Problem of the Right of Publicity}

\section{Context: The Nature of the Right of Publicity}

The "merchandising right" issue has its analog at the state levelstatutory and common law-in the right of publicity and in the struggle of the courts to find appropriate boundaries for that troublesome and confusing construct. It is generally understood that the right of publicity began with a brief 1953 Second Circuit opinion by Judge Jerome Frank (one of the founders of the legal realist movement) holding that a celebrity has a right to damages and other relief for the unauthorized commercial appropriation of the celebrity's persona and that such a right is independent of a common law or a statutory right

89. Id.

90. Dogan \& Lemley, supra note 29 , at $478-93$.

91. Id. at $489-93$.

92. See Justice Scalia's analysis of "trade dress" in Wal-Mart. Wal-Mart Stores, Inc. v. Samara Bros., 529 U.S. 205, 209 (2000). 
of privacy. ${ }^{93}$ By 1953, the courts and the legislatures of the various states had come to recognize a "right of privacy," in the sense of a personal, subjective interest in anonymity. ${ }^{94}$ The task for Judge Frank in Haelan was to separate and differentiate this new "right of publicity" from its ties to the earlier right of privacy. ${ }^{95}$

This separation was predicated on recognition of the decidedly different and purely economic interests in the commercial value of persona. ${ }^{96}$ Judge Frank's focus was on what has since been described as "the marketable product [consisting of] the ability of a person's name or likeness to attract the attention and evoke a desired response in a particular consumer audience. That response is a kind of good will or recognition value generated by that person. . . . While this product is concededly intangible, it is not illusory." 97 The Haelan decision be-

93. Haelan Labs., Inc. v. Topps Chewing Gum, Inc., 202 F.2d 866, 868 (2d Cir. 1953). For present purposes, the right of publicity is considered peculiarly celebrity based, arising only in the case of an individual who has attained some degree of notoriety or fame. See Rogers v. Grimaldi, 875 F.2d 994, 1003-04 (2d Cir. 1989) ("The common law right of publicity, where it has been recognized, grants celebrities an exclusive right to control the commercial value of their names and to prevent others from exploiting them without permission."). Although commentators disagree over whether "celebrity" is a necessary element of the cause of action or relates only to the extent of damages sustained, in practice that debate is largely academic. See, e.g., Martin Luther King, Jr., Ctr. for Social Change, Inc. v. Am. Heritage Prods., Inc., 296 S.E.2d 697, 702-03 (Ga. 1982); see also Tim Frazer, Appropriation of Personality-A New Tort?, 99 Law Q. Rev. 281, 308 (1983). But see Roberta Rosenthal Kwall, Is Independence Day Dawning for the Right of Publicity?, 17 U.C. Davis L. REv. 191, 202-03 (1983) (advocating recognition of a "universal" right of publicity). See generally Sheldon W. Halpern, The Right of Publicity: Commercial Exploitation of the Associative Value of Personality, 39 VAND. L. REv. 1199 (1986) [hereinafter Halpern, Associative Value].

94. See Sheldon W. Halpern, Rethinking the Right of Privacy: Dignity, Decency, and the Law's Limitations, 43 Rutgers L. Rev. 539, 540 (1991) [hereinafter Halpern, Rethinking]. See Bi-Rite Enterps., Inc. v. Button Master, 555 F. Supp. 1188, 1198 (S.D.N.Y. 1983). In Bi-Rite the court explained:

New York's [privacy statute] protects a person's feelings and right to be let alone, ... interests also protected in California, Illinois, and Georgia. Relief is available under the applicable privacy law only for acts that invade plaintiffs' privacy and consequently bruise their feelings. Chief Justice Bird's analysis of the California statute in Lugosi $v$. Universal Pictures ... makes clear that its primary purpose, like that of common law privacy, is to protect the feelings and privacy of the "little man."

Id. (internal citation omitted).

95. See generally Sheldon W. Halpern, The Law of Defamation, Privacy, Publicity and "Moral Rights": Cases and Materials on Protection of Personaltty Interests 491-613 (1988).

96. As the Tenth Circuit observed many years later, "[p]ublicity rights ... are meant to protect against the loss of financial gain, not mental anguish." Cardtoons, L.C. v. Major League Baseball Players Ass'n, 95 F.3d 959, 976 (10th Cir. 1996).

97. Lugosi v. Universal Pictures, 603 P.2d 425, 438 (Cal. 1979) (Bird, C.J., dissenting) (internal citations omitted). 
came the foundation for what is now a widely recognized state ${ }^{98} \mathrm{com}$ mon law or statutory right, ${ }^{99}$ whose independence from whatever privacy-based roots it might have had is generally acknowledged. ${ }^{100}$ Thus, section 46 of the Restatement (Third) of Unfair Competition expressly acknowledges the independent right of publicity: "One who appropriates the commercial value of a person's identity by using without consent the person's name, likeness, or other indicia of identity for purposes of trade is subject to liability for [monetary and injunctive] relief . . .."101

The historical development of the right of publicity, its relation to the right of privacy, its emergence as an independent right, and the maturation and general recognition of that right have been fully described elsewhere. ${ }^{102}$ This now fully mature state-based right is generally recognized either by specific statute or by state common law as protecting the economic interest in an individual's persona. As noted above, for practical purposes, the right is celebrity based: for good or ill, the phenomenon of celebrity generates commercial value. ${ }^{103} \mathrm{Un}$ like that of the "private" person, the celebrity's persona carries with it what has been termed an associative value, the perceived ability to confer value on that which might be associated with the celebrity. ${ }^{104}$

98. "The right of publicity is a creature of state law." ETW Corp. v. Jireh Publ'g, Inc., 332 F.3d 915, 928 (6th Cir. 2003).

99. In California, it is both a common law and a statutory right. See, e.g., Abdul-Jabbar v. Gen. Motors Corp., 85 F.3d 407, 414 (9th Cir. 1996).

100. See generally J. Thomas McCarthy, The Rights of Publicity and Privacy (2d ed. 2008) (providing a comprehensive examination of the right of publicity, its relation to the other interests, and a detailed examination of the state and federal, common-law, and statutory treatment of the subject). Judge Frank's opinion in Haelan is unequivocal in its assumption that the New York Court of Appeals would recognize a common law right of publicity distinct from its statutory privacy right. Haelan Labs., Inc. v. Topps Chewing Gum, Inc., 202 F.2d 866, 868 (2d Cir. 1953). It is, of course, rather ironic that when the New York court finally addressed the question, some thirty years later, it held to the contrary. Stephano v. News Group Publ'ns, Inc., 474 N.E.2d 580, 584 (N.Y. 1984). There, the court stated, "[s]ince the 'right of publicity' is encompassed under the Civil Rights Law as an aspect of the right of privacy, which . . is exclusively statutory ... the plaintiff cannot claim an independent common-law right of publicity." Id. (leaving New York as a prominent exception to the generally recognized proposition concerning the separate status of the right of publicity).

101. Restatement (Third) of Unfair Competition $\$ 46$ (1995).

102. See generally Sheldon W. Halpern, The Right of Publicity: Maturation of an Independent Right Protecting the Associative Value of Personality, 46 Hastings L.J. 853 (1995) [hereinafter Halpern, Maturation]; Michael Madow, Private Ownership of Public Image: Popular Culture and Publicity Rights, 81 Cal. L. Rev. 125, 147-78 (1993).

103. See supra notes $93-101$ and accompanying text.

104. "At its heart, the value of the right of publicity is associational." McFarland v. Miller, 14 F.3d 912, 919 (3d Cir. 1994). See generally Halpern, Associative Value, supra note 93. 
That is, the right of publicity "does not protect one's name per se; rather, it protects the value associated with that name."10s

We accept, as a matter of course, that celebrity will frequently carry with it a marketable component separate from those activities which initially produced the status itself. For example, there is a difference between the value that a successful golf professional such as Tiger Woods gives to an instructional video about golf and the merchandising value that use of his name imparts to a line of $\mathrm{T}$-shirts. It is that latter iteration of the economic value of a persona that informs the right of publicity. However socially useful or detrimental this marketing attribute of celebrity may be,

[i]t would be difficult for any court ... to be unaware of the manner in which celebrities exploit the public's recognition of their name and image. ...

There are few every day activities that have not been touched by celebrity merchandising. . . . These endorsements are of great economic value to celebrities and are now economic reality. ${ }^{106}$

The issue of "value," as the Ninth Circuit has observed, is not a function of merit or desert; rather, it is simply a matter of market place reality:

Television and other media create marketable celebrity identity value. Considerable energy and ingenuity are expended by those who have achieved celebrity value to exploit it for profit. The law protects the celebrity's sole right to exploit this value whether the celebrity has achieved her fame out of rare ability, dumb luck, or a combination thereof. ${ }^{107}$

Of course, as discussed above, the simple assertion of economic reality, understanding that something has value, does not lead inexorably to the conclusion that the law must protect that value. ${ }^{108}$ The emergence and maturation of the right of publicity reflects an American societal determination, through the courts and the legislatures, that the individual's interest in the associative value of his or her persona merits legal protection. When the court observes that "the law protects" the interest, it articulates the policy determination made by the courts and various state legislatures to provide that legal recognition. That determination is by no means universal, as jurisdictions

105. Matthews v. Wozencraft, 15 F.3d 432, 437 (5th Cir. 1994); Comedy III Prods., Inc. v. Gary Saderup, Inc., 21 P.3d 797, 807 (Cal. 2001) ("[T]he right of publicity is essentially an economic right.").

106. Tennessee ex rel. Presley Int'l Mem'l Found. v. Crowell, 733 S.W.2d 89, 94 (Tenn. Ct. App. 1987).

107. White v. Samsung Elecs. Am., Inc., 971 F.2d 1395, 1399 (9th Cir. 1992).

108. See supra notes 101-107 and accompanying text. 
outside of the United States continue to struggle with the fundamental policy determination of whether market place reality justifies legal recognition of the interest; suffice it to say that the American model has become increasingly popular. ${ }^{109}$

\section{The Right of Publicity and Trademark}

The economic reality of a marketable associative value of the personae of some people both distinguishes the right of publicity from privacy rights and establishes its kinship with trademark rights. In essence, as discussed above, both are forms of "appurtenant" rights. ${ }^{110}$ It is not a mere coincidence that recognition of the independent nature of the right of publicity is found in the American Law Institute's Restatement (Third) of Unfair Competition, displacing its earlier home in the Restatement (Second) of Torts. ${ }^{111}$ Nor is it a mere coincidence that as the right of publicity has matured, it has been increasingly connected to trademark rights. As a matter of practice, it is quite common to couple allegations of violation of the right of publicity with claims for trademark infringement under the Lanham Act, either as registered marks (when the plaintiff's name has in fact been registered), or as unregistered marks under section 43(a). ${ }^{112}$ Although "as a general rule, a person's image or likeness cannot function as a trademark," "[c]ourts have recognized false endorsement claims under Section 43(a) of the Lanham Act where a celebrity's image or persona is used in association with a product so as to imply that the celebrity endorses the product."113 To a fair extent, this use of section 43(a) creates a federal variant of the state law right of publicity claim. ${ }^{114}$

The federal variant is, to be sure, not a true analogue. For the section 43(a) claim, as with any trademark claim, the allegedly wrongful use must create a "likelihood of confusion" with respect to the source,

109. See Huw Beverley-Smith, The Commercial Appropriation of Personality (2002) (discussing activities in the United Kingdom and other jurisdictions relating to their versions of the right of publicity). Smith states, "[t]o American lawyers, the whole project [i.e., the United Kingdom inquiry into the extent to which to recognize these rights] may have a vaguely nineteenth-century feel, as the English courts continue to debate whether to recognise interests that the US courts have recognised and protected in various forms for over a century." Id. at xi.

110. See supra notes $24-25$ and accompanying text.

111. See Restatement (Third) of Unfair Competition $\$ 46$ (1995); Restatement (SeCOND) OF TORTS $\S 652 C(1977)$.

112. See 15 U.S.C. $\$ 1114,1125$ (a) (2000); ETW Corp. v. Jireh Publ'g, Inc., 332 F.3d 915, 919 (6th Cir. 2003); White, 971 F.2d at 1396; Waits v. Frito-Lay, Inc., 978 F.2d 1093, 1096 (9th Cir. 1992).

113. ETW Corp., 332 F.3d at $922,925$.

114. See id. at 924. 
origin, or endorsement or sponsorship of goods or services. ${ }^{115}$ In the classic right of publicity situation, the appropriation of the associative value of the persona would normally give rise at least to confusion as to "endorsement" of the user's goods or services. ${ }^{116}$ But such "endorsement" confusion, while often present, is not essential to the publicity claim, if one can otherwise demonstrate that the value of the persona has been associated with the offending product. "Although publicity rights are related to laws preventing false endorsement, they offer substantially broader protection."117 In any event, the kinship between the federal trademark construct and the widely recognized state law right is evident and the experience with each may usefully inform the process of creating appropriate boundaries for each.

\section{The Boundaries Inherent in the Right of Publicity}

The right of publicity involves a communicative tort; it necessarily implicates speech and therefore raises First Amendment concerns. The interconnection between publicity rights and First Amendment rights to free expression has caused a fair amount of judicial anguish and accompanying complexity in dealing what would otherwise seem to be a rather simple issue. As the comments to the Restatement (Third) of Unfair Competition note, "[t]he right of publicity as recognized by statute and common law is fundamentally constrained by the public and constitutional interest in freedom of expression."118 This constraint is part of the very nature of the right, however, as any claim must be based on the commercial appropriation of identity; news, information, even entertainment uses, by the very definition of the right, ${ }^{119}$ are outside its scope. Thus, while using a celebrity as the subject of a book, play, or magazine or newspaper article usually involves

115. Lanham Act $\S 43(a), 15$ U.S.C. $\S 1125(a)$.

116. ETW Corp., 332 F.3d at 925-926.

117. Cardtoons, L.C. v. Major League Baseball Players Ass'n, 95 F.3d 959, 967 (10th Cir. 1996). The court offered an example:

Suppose, for example, that a company, Mitchell Fruit, wanted to use pop singer Madonna in an advertising campaign to sell bananas, but Madonna never ate its fruit and would not agree to endorse its products. If Mitchell Fruit posted a billboard featuring a picture of Madonna and the phrase, "Madonna may have ten platinum albums, but she's never had a Mitchell banana," Madonna would not have a claim for false endorsement. She would, however, have a publicity rights claim, because Mitchell Fruit misappropriated her name and likeness for commercial purposes. Publicity rights, then, are a form of property protection that allows people to profit from the full commercial value of their identities.

Id. at 967-68; see also Abdul-Jabbar v. Gen. Motors Corp., 85 F.3d 407 (9th Cir. 1996).

118. Restatement (Third) of Unfair Competition $\S 47 \mathrm{cmt}$. c (1995).

119. Many jurisdictions also limit the right directly in their statutes. See generally McCARTHY, supra note 100. 
a measure of gain for the author or publisher, such entertainment or newsworthy uses are beyond the reach of the right of publicity. ${ }^{120}$ The broad "newsworthiness" shelter"121 that insulates many uses of an individual's identity from right of privacy claims ${ }^{122}$ is no less applicable to the right of publicity, ${ }^{123}$ and it has been the means by which courts have consistently defined the ambit of constitutionally protected dissemination of ideas. ${ }^{124}$ As the Restatement (Third) of Unfair Competition makes clear, the right of publicity does not ordinarily extend to "the use of a person's identity in news reporting, commentary, entertainment, works of fiction or nonfiction, or in advertising that is incidental to such uses."125 As I have suggested elsewhere:

The right of publicity does not reach beyond the interest it is designed to protect, i.e., the associative value, the hard economic commercial value of an individual's identity, and thus is limited to commercial exploitative uses. It is this exploitative appropriation of a property interest, and not simply a formulaic approach to commercial speech, that precludes First Amendment protection for the appropriator. As a result, for the most part, First Amendment policy considerations have little impact on the avowedly commercial appropriation of identity, the classic right of publicity case. ${ }^{126}$

In short, despite some judicial indulgence in a kind of deconstructive critique of the right itself, ${ }^{127}$ as properly understood, the right of publicity is not inconsistent with newsworthy, entertainment, critical, satirical, or parodic uses. ${ }^{128}$ A television program that simply provides information about an athlete's achievements would not implicate the

120. See, e.g., New Kids on the Block v. News Am. Publ'g, Inc., 971 F.2d 302, 308 (9th Cir. 1992).

121. The newsworthiness limitation "is one of constitutional dimension ... controlled by federal rather than state law." Virgil v. Time, Inc., 527 F.2d 1122, 1129 (9th Cir. 1975). See generally Halpern, Rethinking, supra note 94.

122. See HALPERN, supra note $95, \S 2.5$ (“'[N] ewsworthiness' may arise from the plaintiff's status as a 'public figure' or from the legitimate public interest in the subject matter. However it arises, it confines the right of privacy."). See, e.g., Freihofer v. Hearst Corp., 480 N.E.2d 349, 354 (N.Y. 1985).

123. HALPERN, supra note $95, \S 3.3(\mathrm{~B})$.

124. See, e.g., Hoffman v. Capital Cities/ABC, Inc., 255 F.3d 1180, 1186 (9th Cir. 2001); Stephano v. News Group' Publ'ns, Inc., 474 N.E.2d 580, 585 (N.Y. 1984).

125. Restatement (Third) of Unfair Competition $\$ 47$ (1995).

126. Halpern, Rethinking, supra note 94 , at 868.

127. See Cardtoons, L.C. v. Major League Baseball Players Ass'n, 95 F.3d 959 (10th Cir. 1996) (containing a rather labored analysis); C.B.C. Distribution \& Mktg., Inc. v. Major League Baseball Advanced Media, L.P., 505 F.3d 818 (8th Cir. 2007).

128. For example, the court in Cardtoons noted: "Because celebrities are an important part of our public vocabulary, a parody of a celebrity does not merely lampoon the celebrity, but exposes the weakness of the idea or value that the celebrity symbolizes in society." Cardtoons, 95 F.3d at 972. 
right of publicity, ${ }^{129}$ whereas such implication would arise from a television advertisement that uses that information about an athlete to call attention to and to frame the advertiser's commercial advertising; the liability arises not simply from the mere fact of using the athlete's name, but in doing so in a manner that associates the athlete with the product. ${ }^{130}$

Despite the occasional commentary viewing the right of publicity with alarm, ${ }^{131}$ except perhaps at the margins, the right easily coexists with the First Amendment. Even at the margins, as with related trademark issues, the courts have been quite ready to recognize and address appropriate First Amendment concerns. As the Second Circuit observed in Rogers $v$. Grimaldi, ${ }^{132}$ which involved both trademark and right of publicity claims arising out of the use of a well-known actress's name in the title of a motion picture:

Because overextension of Lanham Act restrictions in the area of titles might intrude on First Amendment values, we must construe the Act narrowly to avoid such a conflict....

... We believe that in general the Act should be construed to apply to artistic works only where the public interest in avoiding consumer confusion outweighs the public interest in free expression. ${ }^{133}$

A sophisticated, nuanced approach, predicated on an understanding of the associative, appurtenant nature of the right of publicity can obviate apparent problems. For example, in Rogers, Judge Newman observed that the use of the name of the actress Ginger Rogers in the phrase "Fred and Ginger," as part of the title of a motion picture about the travails of an Italian dance team, was not an appropriation of her name, or exploitation of the value of her name. ${ }^{134}$ Rather, her "name" was used in an iconic sense, a kind of shorthand in which the phrase "Fred and Ginger" did not refer so much to the specific people (Fred Astaire and Ginger Rogers) as it did to the form of elegant ballroom dancing that they had come to represent. ${ }^{135}$ That is, some as-

129. As the comments to the Restatement (Third) of Unfair Competition put it: "The use of a person's identity primarily for the purpose of communicating information or expressing ideas is not generally actionable as a violation of the person's right of publicity." Restatement (ThIRD) OF UnFaIR COMPETTTION $\$ 47 \mathrm{cmt}$. c (1995).

130. Abdul-Jabbar v. Gen. Motors Corp., 85 F.3d 407, 412 (9th Cir. 1996).

131. See, e.g., Madow, supra note 102, at 178; George M. Armstrong, Jr., The Reification of Celebrity: Persona as Property, 51 LA. L. Rev. 443 (1991).

132. 875 F.2d 994 (2d Cir. 1989).

133. $I d$. at $998-99$.

134. Id. at 1001.

135. Id. The Second Circuit noted: 
pect of a celebrity may transcend his or her own persona and become evocative of a more general, if not generic, concept involving use of language rather than use of persona. The inappropriateness of the right of publicity in such a situation is self-evident. Although much may be said in favor of categorical rules under appropriate circumstances, ${ }^{136}$ in dealing with the interface between language and persona, the idea of "name" is much too flexible to give rise to a categorical rule supplanting analysis. ${ }^{137}$ "The scope of a rule is often ... limited by its rationale. Or, to make the same point differently, one way of going astray in legal analysis is to focus on the semantics of a rule rather than its purpose." 138

To Shakespeare's question, "What's in a name?," the lawyer looking at a trademark or publicity claim might well respond "it depends on the circumstances."

Such a circumstantial analysis (applied to the image evoked by Vanna White) might have been used to avoid the controversial result in the Ninth Circuit's White v. Samsung opinion. ${ }^{139}$ A nuanced analysis of publicity claims would recognize that use of a name or image or other indicia of persona does not per se implicate the right of publicity

\footnotetext{
As Fellini explains in an affidavit, Rogers and Astaire are to him "a glamorous and care-free symbol of what American cinema represented during the harsh times which Italy experienced in the 1930s and 1940s." In the film, he contrasts this elegance and class to the gaudiness and banality of contemporary television, which he satirizes. Id.
}

136. See, e.g., Wal-Mart Stores, Inc. v. Samara Bros., 529 U.S. 205, 213, 216 (2000) (adopting a categorical rule precluding inherent distinctiveness for product design).

137. See Peaceable Planet v. Ty Inc., 362 F.3d 986, 989 (7th Cir. 2004) (involving the name "Niles" for a toy stuffed camel, in which Judge Posner refused to apply a categorical rule with respect to trademark distinctiveness and "names" merely because the mark at issue could also serve as a person's name).

138. Id. at $989-90$.

139. White v. Samsung Elecs. Am., Inc., 971 F.2d 1395, 1396 (9th Cir. 1992). The case involved a Samsung advertisement for a videocassette recorder that pictured a robot, dressed in a wig, gown, and jewelry "consciously selected to resemble [Vanna] White's hair and dress. The robot was posed next to a game board which is instantly recognizable as the Wheel of Fortune game show set, in a stance for which White is famous." Id. As I noted elsewhere:

In this context, it is arguable that the defendants did not so much appropriate Vanna White's identity as they used it to evoke the subject (i.e., the Wheel of Fortune game show) with which she has been associated. . . Arguably, it is not Vanna White, but a role she has come to epitomize, that was the subject of the advertisement. One may well claim that for purposes of Wheel of Fortune or a similar game show, Vanna White has become "generic," her name and general "dressed-up" appearance a shorthand way of referring to a type, so that any other woman, similarly dressed and performing a similar act, even if otherwise totally unlike White, might be described as being another "Vanna." ... The defendants used the White stereotype, but not necessarily to evoke her. The "generic" defense was rejected by the White majority, but without serious analysis of its specific application to the facts there.

Halpern, Maturation, supra note 102, at 864-65. 
and that a contextual analysis of the use is necessary in order to determine if there has been an appropriation of the associative value of the persona. That analytic model, rather than a categorical conclusion, provides one of the requisite boundaries that allows a robust right of publicity to exist easily with free expression. We should consider merchandising and the right of publicity within the context of these boundaries, just as we must consider merchandising and trademark rights within the context of the proper boundaries of trademark law.

\section{Publicity and "Merchandising Rights"}

Perhaps the most interesting boundary, albeit one that seems counterintuitive, concerns a kind of "merchandising" right, analogous to the attempt to create independent rights in a trademark itself. Briefly, the right of publicity, if fully understood as an appurtenant, associative right, is inapplicable to commercial use of the persona itself independent of an association with another person or another's goods or services. In short, just as a trademark is not an independent form of property and trademark law per se, it should not be construed to embrace a separate merchandising right in a trademark, the right of publicity (the associative economic construct) is not an independent form of property in persona and therefore it similarly should not be construed to embrace an independent merchandising right.

Before the right of publicity emerged from its privacy moorings and was simply and erroneously considered the "appropriation branch" of the right of privacy, it was assumed that, just as with the right of privacy, any trafficking in anyone's image for commercial purposes gave rise to a claim within the statutory or common law limitations. ${ }^{140}$ In the context of the right of privacy, a clearly commercial public dissemination of an individual's image, without consent, will support a privacy claim by the person pictured. ${ }^{141}$ The only serious issue in privacy litigation in those circumstances would be whether the otherwise commercial use could be saved by some reasonable tie to "newsworthiness." 142 Accordingly, in that privacy context, our concern is solely with the public and commercial dissemination of the image; association with the person disseminating that image or with any goods or services would be irrelevant. Thus, when Time, Inc., as the owner of the well-known Eisenstadt photograph, The Kissing Sailor, attempted,

140. See Titan Sports, Inc. v. Comics World Corp., 870 F.2d 85, 88 (2d Cir. 1989).

141. See, e.g., Messenger v. Gruner + Jahr Printing \& Publ'g, 727 N.E.2d 549, 554 (N.Y. 2000).

142. See id. 
many years after the initial (and clearly newsworthy ${ }^{143}$ ) publication of the photo, to offer copies of the photo for sale to the public, the court had little difficulty upholding a cause of action by the pictured "sailor" for violation of his right of privacy. ${ }^{144}$

On superficial analysis, it seems quite logical to transfer this privacy-based proposition to the right of publicity. Thus, there was no question under Georgia law that if Dr. Martin Luther King, Jr.'s right of publicity were descendible, his estate would have a claim against one who sold, without consent, statuettes of Dr. King. ${ }^{145}$ The Georgia Supreme Court, answering questions certified to it by a federal court, recognized the descendibility and consequently the viability of the cause of action for violation of the late Dr. King's "right of publicity."146

Similarly, the estate of Elvis Presley has vigorously pursued right of publicity claims against those purporting to sell Presley photos or memorabilia. ${ }^{147}$ More recently, right of publicity claims were brought against the sale of lithographs and T-shirts bearing drawings of the images of the Three Stooges ${ }^{148}$ and serigraphs and lithographs of a painting of the professional golfer, Tiger Woods. ${ }^{149}$ As discussed below, the courts in these cases assume the applicability of the common law or statutory rights of publicity to the defendants' use of the images. ${ }^{150}$ The issue in litigation was whether the court should construct a complex "fair use" or First Amendment "exception" to the right.

In the Three Stooges case, Comedy III, the California Supreme Court, while ultimately holding for the plaintiff, the assignee of the Stooges' publicity rights, sought to "resolve a conflict" between the right of publicity and the First Amendment and to "to develop a test

143. Mendonsa v. Time, Inc., 678 F. Supp. 967, 972 (D.R.I. 1988). Alfred Eisenstadt took a famous photograph of an unnamed sailor kissing a nurse during a celebration of the end of World War II in 1945, and it was contemporaneously published in Life magazine as part of a news story covering the event. Id. at 968 .

144. Id. at 972.

145. Martin Luther King, Jr., Ctr. for Social Change, Inc. v. Am. Heritage Prods., Inc., 296 S.E.2d 697, 705-06 (Ga. 1982).

146. $I$.

147. See, e.g., Factors Etc., Inc. v. Pro Arts, Inc., 579 F.2d 215, 222 (2d Cir. 1978) (finding descendibility); Memphis Dev. Found. v. Factors Etc., Inc., 616 F.2d 956, 958 (6th Cir. 1980) (refusing to find descendibility under Tennessee law, a determination subsequently questioned by Tennessee courts); Factors Etc., Inc. v. Pro Arts, Inc., 652 F.2d 278, 283 (2d Cir. 1981) (applying Memphis Development to reverse the descendibility holding in the Second Circuit's earlier ruling). See Halpern, Rethinking, supra note 94, at 605-17.

148. Comedy III Prods., Inc. v. Gary Saderup, Inc., 21 P.3d 797, 797 (Cal. 2001).

149. ETW Corp. v. Jireh Publ'g, Inc., 332 F.3d 915, 918 (6th Cir. 2003).

150. See infra notes $151-162$ and accompanying text. 
that will unerringly distinguish between forms of artistic expression protected by the First Amendment and those that must give way to the right of publicity." 151 It proposed borrowing the "fair use" construct of "transformative use" from the United States Supreme Court's copyright opinion in Campbell $v$. Acuff-Rose Music, Inc. ${ }^{152}$ The court found the Campbell inquiry into whether a work is "transformative" "to be necessarily at the heart of any judicial attempt to square the right of publicity with the First Amendment."153 The court noted:

When artistic expression takes the form of a literal depiction or imitation of a celebrity for commercial gain, directly trespassing on the right of publicity without adding significant expression beyond that trespass, the state law interest in protecting the fruits of artistic labor outweighs the expressive interests of the imitative artist... .

On the other hand, when a work contains significant transformative elements, it is not only especially worthy of First Amendment protection, but it is also less likely to interfere with the economic interest protected by the right of publicity. . . .

.... We ask, in other words, whether a product containing a celebrity's likeness is so transformed that it has become primarily the defendant's own expression rather than the celebrity's likeness. ...

In sum, when an artist is faced with a right of publicity challenge to his or her work, he or she may raise as affirmative defense that the work is protected by the First Amendment inasmuch as it contains significant transformative elements or that the value of the work does not derive primarily from the celebrity's fame. ${ }^{154}$

Concluding that the defendant's drawings, however skillful they might be, were simply appropriative of the images without any transformative effects, the court held for the plaintiff. ${ }^{155}$

In $E T W$ a divided Sixth Circuit panel concluded that the painting at issue "ha[d] substantial informational and creative content which outweigh[ed] any adverse effect on ETW's market and that [the] work does not violate [Tiger] Woods's right of publicity."156 The court then expressly adopted the Ninth Circuit's Comedy III "transformative use" model and, finding that the defendant's image of Tiger Woods in

151. Comedy $I I I, 21$ P.3d at 807.

152. Id. (citing Campbell v. Acuff-Rose Music, Inc., 510 U.S. 569 (1994)).

153. Id. at 808 .

154. Id. at 808-10 (internal citations omitted).

155. Id. at 811 . "[W]e can discern no significant transformative or creative contribution. His undeniable skill is manifestly subordinated to the overall goal of creating literal, conventional depictions of The Three Stooges so as to exploit their fame." Id.

156. ETW Corp. v. Jireh Publ'g, Inc., 332 F.3d 915, 937 (6th Cir. 2003). 
the Masters of Augusta painting ${ }^{157}$ sold by defendant was sufficiently "transformative," concluded that "Woods's right of publicity must yield to the First Amendment."158

These judicial approaches to merchandising the persona itself, much like merchandising a trademark itself, are at best needlessly complex and, more seriously, less than helpful in providing a consistent and predictable set of limits on the right of publicity. Thus, while two members of the ETW panel found the painting "transformative" and protected, the third vigorously dissented and called for summary judgment for the plaintiff on the right of publicity claim; the dissent, while also adopting the Comedy III framework, found nothing "transformative" in the defendant's work. ${ }^{159}$ Post hoc determinations of what is "transformative" are inherently idiosyncratic.

As the California Supreme Court itself points out in Comedy III, the copyright fair use analogy is an imperfect guide for use in analyzing the right of publicity. ${ }^{160}$ It is abundantly clear, from the complex, lengthy, and somewhat tortured exercises of the courts in dealing with the problem of marketing the persona itself, that the courts are uncomfortable. The attempt to engraft onto the right of publicity the highly nuanced copyright fair use construct in these circumstances, much as the related application of the copyright "first sale" doctrine to shelter re-sales of a celebrity image, ${ }^{161}$ reflects this discomfort; it is a recognition that the right of publicity does not really fit here. We must of course use the best tools available under the circumstances and quite often (as can be the case with categorical rules) predictability and consistency are not necessarily the optimal result.

Certainly, the law, and many areas of intellectual property law in particular, must accommodate to uncertainty; living with post-hoc determinations and their consequence of limited predictability is often

157. Id. at 938. As the court describes it:

In the foreground of 'Rush's painting are three views of Woods in different poses. In the center, he is completing the swing of a golf club, and on each side he is crouching, lining up and/or observing the progress of a putt. To the left of Woods is his caddy, Mike "Fluff" Cowan, and to his right is his final round partner's caddy. Behind these figures is the Augusta National Clubhouse. In a blue background behind the clubhouse are likenesses of famous golfers of the past looking down on Woods.

Id. at 918 .

158. Id. at 938 .

159. Id. at 938,959 (Clay, J., dissenting) ("[I]t is difficult to discern any appreciable transformative or creative contribution in Defendant's prints so as to entitle them to First Amendment protection.").

160. Comedy $I I I, 21$ P.3d at 807 ("[A] wholesale importation of the fair use doctrine into right of publicity law would not be advisable.").

161. Allison v. Vintage Sports Plaques, 136 F.3d 1443, 1448 (11th Cir. 1998). 
the optimal approach to some complex problems. ${ }^{162}$ But we should choose the path of uncertainty only where there is not a viable and more predictable alternative consistent with the underlying legal principles. It seems to me that with respect to the right of publicity analogue to "merchandising" rights, there is such an alternative, predicated on the inherent nature of the right of publicity.

A sophisticated understanding of the right of publicity (as distinct from its privacy antecedent) as a right apppurtenant, much like a trademark, whose function is to protect the interest in the economic associative value of a well known persona, leads to the conclusion that the right does not itself extend to exploitation of the persona standing alone. In Comedy III, Judge Mosk expressly rejected the suggestion that, for right of publicity liability under the California statutes, the sale of the images themselves, as embodied in lithographs and T-shirts did not amount to the use of the images "on or in products" or merchandise, as required by California law. ${ }^{163}$ Instead, he found that "Saderup's lithographic prints of The Three Stooges are themselves tangible personal property, consisting of paper and ink, made as products to be sold and displayed on walls like similar graphic art. Saderup's T-shirts are likewise tangible personal property, consisting of fabric and ink, made as products to be sold and worn on the body like similar garments." 164 The court skimmed the surface of the question and could well have pursued it more deeply. The matter is reminiscent of the Tenth Circuit's Giles opinion, ${ }^{165}$ with its holding that patches and labels bearing counterfeit trademarks are not "goods" for purposes of the criminal statute. ${ }^{166}$ If we start with the fundamental construct of associative value ${ }^{167}$ on which the right of publicity is predicated, then conceptually that right is not implicated absent circumstances in which the persona is associated with another's product or service. ${ }^{168}$ Indeed, it is that association, the imparting of the economic

162. The copyright construct of fair use is certainly a prime example of that kind of necessary uncertainty. Dellar v. Samuel Goldwyn, Inc., 104 F.2d 661, 662 (2d Cir. 1939) ("[T]he doctrine of fair use is the most troublesome in the whole law of copyright."); see Pierre N. Leval, Toward a Fair Use Standard, 103 HARv. L. Rev. 1105, 1105-07 (1990). Similarly, the courts have had to accommodate to the inherent unpredictability in applying the doctrine of "conceptual separability" to articles of industrial design. See, e.g., Brandir Int'l, Inc. v. Cascade Pac. Lumber Co., 834 F.2d 1142, 1143 (2d Cir. 1987) (Conceptual seperability exists where "artistic judgment is exercised independent of functional influences.").

163. Comedy $I I I, 21$ P.3d at 801-02.

164. Id.

165. United States v. Giles, 213 F.3d 1247, 1251 (10th Cir. 2000).

166. Id.; see also supra notes $78-82$ and accompanying text.

167. See supra notes 102-107 and accompanying text.

168. As one court noted: 
value of the persona to something else, that lies at the heart of the separation of publicity rights from privacy rights and distinguishes this economic right. We do not need to resolve here the question whether a celebrity, someone who has chosen to be exposed regularly to the public, can assert traditional privacy rights. ${ }^{169}$ Nor is the general issue of rights under specific privacy statutes within the scope of the present discussion. The concern here is simply over the assertion of statutory ${ }^{170}$ or common law right of publicity claims in connection solely with the merchandising of the persona itself, as in ETW or Comedy III. If such claims are to be sustained, the rationale for doing so is inherently different from that upon which the right of publicity is based and therefore, they must be founded on something other than the right of publicity.

Realistically, in that context what is being sold is the image itself and not something else to which that image might lend value. Standing alone, the fact that the image is embodied tangibly in the paper of a lithograph or the fabric of a $\mathrm{T}$-shirt should no more implicate an association of the person depicted with the seller, than the embodiment of the "Job's Daughters" insignia in a signet ring implicates the trademark rights of the International Order of Job's Daughters. ${ }^{171}$

\section{Conclusion: Applying Occam's Razor To Preserve the Fundamental Balance}

The approach to merchandising rights with respect to both trademarks and celebrity images has been needlessly complex and demands simplification. The Supreme Court, with its strong admonition to restore and recognize the balance among the different intellectual prop-

We conclude that the district court properly determined that, as a matter of law, Vintage merely resells cards that it lawfully obtains. ... We think it unlikely that anyone would purchase one of Vintage's plaques for any reason other than to obtain a display of the mounted cards themselves. Although we recognize that the plaques that include a clock pose a closer case, we conclude that it is unlikely that anyone would purchase one of the clock plaques simply to obtain a means of telling time, believing the clock to be, for example, a "Hershisher Clock" or an "Allison Clock."

Allison v. Vintage Sports Plaques, 136 F.3d 1443, 1450-51 (11th Cir. 1998).

169. Compare Bi-Rite Enters., Inc. v. Button Master, 555 F. Supp. 1188, 1198 (S.D.N.Y. 1983) ("[A]s public figures, with their likenesses, names and images already in the public domain, [plaintiffs] have waived their rights to claim intrusions into their common law privacy rights."), with Ann-Margret v. High Soc'y Magazine, Inc., 498 F. Supp. 401, 404 (S.D.N.Y. 1980) ("It is clear that a public figure does not, simply by virtue of his or her notoriety, lose all rights to privacy.").

170. Of course, there are many statutory variations on the right, with a plethora of specific limitations and exceptions. See generally MCCARTHY, supra note 100.

171. Int'l Order of Job's Daughters v. Lindeburg \& Co., 633 F.2d 912, 920 (9th Cir. 1980); see supra notes $72-75$ and accompanying text. 
erty constructs, has provided the broad framework within which such simplification can be realized. We start by recognizing that trademark rights are essentially appurtenant, conditional rights, rather than selfsustaining property rights. That leads to the conclusion that trademark law cannot be the vehicle for enforcing claims arising out of the merchandising of the mark itself, absent clear evidence of real (rather than spurious) consumer confusion as to source, origin, or sponsorship of goods or services. ${ }^{172}$ In the same vein, the right of publicity, if properly understood and bounded, similarly is an appurtenant right, rather than an absolute exclusionary right in a name or image; that recognition accordingly precludes a publicity claim based solely on exploitation of the image itself without association with the user of the image. A focus on the fundamental nature of the underlying legal constructs of trademark law and of the cognate right of publicity allows application of a conceptual occam's razor, a simplification that sets the proper boundaries and balance.

172. "The zeal to protect the full value of marks, and the feelings and economic interests that fuel it ... cannot negate the fact that unfair competition law clearly requires confusion as to the source of goods before it will protect against the unauthorized use of a mark." Bi-Rite, $555 \mathrm{~F}$. Supp. at 1194. 
